\title{
STUDI KOMPARASI OPTIMASI PARTICLE SWARM DAN ALGORITMA GENETIKA PADA PERANCANGAN FOIL
}

\author{
Eva Hertnacahyani Herraprastanti 1), Helmi Gunawan ${ }^{2)}$, Eko Budi Santoso ${ }^{3)}$ \\ ${ }^{1}$ Teknik Mesin, Sekolah Tinggi Teknologi Ronggolawe Cepu \\ 2 Teknik Mesin, Sekolah Tinggi Teknologi Ronggolawe Cepu \\ ${ }^{3}$ Teknik Mesin, Politeknik SAKTI Surabaya
}

Email : ev.hertna@gmail.com, helmig87@gmail.com, azizankoe@gmail.com

\begin{abstract}
Foil is a ship installed wings at bottom of hull support. If the speed's ship increases, foil will produce a lift that causes the hull rised and exit from the water. Therefore, there will be a reduction in friction force that results in the ship's velocity increase. The choice of foil is important to improve the ship performance. The study aims to compare 2 optimization methods, namely Genetic Algorithm (GA) and Particle Swarm (PSO) produce maximum lift and minimum drag. The designed foil is Joukowsky type with angle of attack $2^{\circ}, 4^{\circ}, 6^{\circ}, 8^{\circ}, 10^{\circ}$ and 150,000 Reynold numbers. The method is used to state initial geometry of Joukowsky foil, iterated JavaFoil, optimized by GA and PSO using GNU Octave software. They are compared foil produces the maximum optimum $C_{L} / C_{D}$ value. Validation of lift coefficient $\left(C_{L}\right)$ and drag $\left(C_{D}\right)$ Airfoil $S 9000$ is almost similiar with the Williamson experiment. Stall is at angle of attack $9.3^{\circ}$, with $C_{L}$ error of $3.66 \%, C_{D}$ error of $6.83 \%$. It results in the allowed tolerances are below 9.5\%. Validation with JavaFoil Solver shows accurate results, with error of $4.15 \%$. GA optimization produces $C_{L} / C_{D}$ averages of 41,777 so it grows $6,544 \%$. Whereas the $C_{L} / C_{D}$ average PSO is 36,197, improve of 4,793\%. GA optimization has a fairly high convergence speed at the first, then followed by stagnation process, the resulted solution improves significantly. PSO is focused on local search so convergence is difficult to achieve. The recommended foil optimization is to use GA.
\end{abstract}

Keywords: Drag, GA, Hydrofoil, Lift, PSO

\section{PENDAHULUAN}

Foil merupakan kapal yang dipasangi sayap di bagian bawah penyangga lambung kapal. Ketika kecepatan kapal meningkat, foil akan menghasilkan lift yang menyebabkan lambungnya terangkat dan keluar dari air. Oleh karena itu akan terjadi pengurangan gaya gesek yang mengakibatkan kecepatan kapal menjadi meningkat. Cara kerja foil hampir sama dengan kapal laut. Hanya saja foil dirancang seperti sayap yang dapat melintasi air dan meluncur dengan kecepatan timggi. Sayap yang ada pada foil menempel pada topangan y ang terbentang di bawah lambung kapal. Menurut Wonggiawan (2015), dalam kendaraan ini terdapat dua pasang foil, yaitu yang diletakkan di pusat gravitasi kapal dan sepasang lainnya diletakkan di dekat bagian belakang kapal.

Ketika foil meluncur dengan kecepatan rendah sampai sedang, akan terlihat seperti kapal biasa yang badannya masuk ke dalam air. Akan tetapi ketika berkecepatan tinggi, air laut akan membelok dari permukaan atas foil, seperti halnya udara yang membelok dari permukaan atas pesawat terbang, sebaliknya tekanan air pada permukaan foil bagian atas menjadi menurun. Tekanan yang semakin menurun ini akan menimbulkan lift, dan jika semakin banyak lift yang ditimbulkan, maka bagian haluan kapal akan muncul ke atas permukaan air, sehingga seluruh lambung kapal akan naik dari permukaan air. Kapal akan terlihat seperti "menggantung pada air". Pemilihan foil menjadi salah satu aspek yang penting dalam meningkatkan prinsip kerja kapal (Suryadi, 20 17). Tujuan penelitian ini adalah melakukan perbandingan 2 metode optimasi, yaitu Algoritma Genetika (GA) (Quagiarella \& Vicini, 200 1), dan Particle Swarm Optimization (PSO) (Khurana \& Massey, 2015) dalam perancangan 
foil yang dapat menghasilkan lift maksimal dan drag minimal, bantuan software GNU Octave (Herraprastanti, 2018).

Foil y ang dirancang dalam penelitian ini adalah tipe Joukowsky (Ashraf, 2011) angle of attack antara $2^{\circ} \mathrm{s} / \mathrm{d} 10^{\circ}$ dengan step $2^{\circ}$, bilangan Reynold 150,000. Profil foil yang dirancang dalam penelitian ini nantinya y ang memiliki rasio koefisien lift $\left(C_{L}\right)$ terhadap koefisien drag $\left(C_{D}\right)$ atau $C_{L} / C_{D}$ maksimum.

Penelitian ini mengacu pada penelitian Khurana dan Sinha (2015) yang mengkaji aplikasi algoritma Particle Swarm Optimization (PSO) untuk optimasi bentuk airfoil. Metodologi optimasi yang diterapkan meliputi integrasi fungsi bentuk Parsec untuk representasi bentuk airfoil, algoritma swarm sebagai agen pencari dan model ANN untuk perhitungan. PSO diusulkan untuk pengujian dua varian. Hasilnya dipetakan ke grafik yang menunjukkan bahwa model tersebut adaptif dan cocok untuk aplikasi desain airfoil. Model yang diusulkan membutuhkan desain lebih lanjut, pengembangan dan validasi untuk mengurangi persentase kesalahan simulasi.

Mukesh, R., dkk. (2012) dalam jurnal Procedia Engineering, mengkaji tentang optimasi bentuk aerodinamik pada sayap pesawat pengaruhnya jika menggunakan pendekatan algoritma. Metode algoritma yang digunakan untuk memecahkan masalah optimasi bentuk aerodinamis antara lain Algoritma Genetika (GA), Annealing Simulasi (SA), dan optimasi menggunakan Particle Swarm (PSO), dll. Selain metode optimasi, parameterisasi geometri juga menjadi faktor penting yang harus dipertimbangkan dalam proses optimasi bentuk aerodinamis. Karena pengurangan jumlah parameter desain merupakam salah satu persyaratan y ang paling penting dalam masalah optimasi bentuk aerodinamis, dan tak kalah pentingnya adalah menggambarkan secara matematis geometri airfoil dalam jumlah minimum parameter desain. Tujuan dari penelitian ini adalah untuk memperkenalkan pengetahuan penggambaran geometrik airfoil umum menggunakan dua belas parameter dan bisa mewakili bentuknya sebagai fungsi polinomial dan pendekatan kopel dengan solusi aliran dan algoritma optimasi. Masalah optimasi bentuk aerodinamis diformulasikan untuk airfoil NACA 0012 dan diselesaikan dengan menggunakan metode PSO dan GA pada sudut serang 5,0 derajat. Hasilnya menunjukkan bahwa skema optimisasi partikel swarm lebih efektif dalam mencari solusi optimal di antara berbagai kemungkinan solusi. Ditemukan juga bahwa PSO menunjukkan lebih banyak karakteristik eksploitasi dibandingkan dengan GA yang dianggap lebih efektif sebagai penjelajah.

Mukesh dan Lingadurai (2013) mencoba mengoptimasi bentuk airfoil menggunakan teknik optimasi dan validasi non-tradisional pada airfoil NACA 2411. Selama proses optimasi bentuk aerodinamis airfoil digambarkan menggunakan parameterisasi Parsec. Aliran di sekitar airfoil diselesaikan dengan menggunakan Metode Panel. Optimasi dilakukan dengan menggunakan Algoritma Genetika. Airfoil optimal diamati melalui eksperimen terowongan angin. Distribusi koefisien tekanan dan lift dihitung pada sudut serang $5^{\circ}$ kemudian dibandingkan dengan nilainilai yang diperoleh dari proses optimasi yang dilakukan oleh GA. Dari parameter aerodinamis, teramati bahwa hasil yang dihasilkan oleh GA untuk airfoil optimal selama optimasi yang cukup dekat dengan hasil yang diperoleh dari pengukuran menggunakan terowongan angin. Persentase kesalahan antara komputasi dan hasil eksperimen adalah 4\%. Dapat disimpulkan bahwa proses optimasi bentuk aerodinamis menggunakan GA ini cukup akurat untuk digunakan pada tahap awal proses desain airfoil. Kesimpulan ini dapat digunakan pada tahap lanjut desain airfoil jika solusi panel digantikan oleh algoritma tingkat tinggi.

Chaves (2012), mengkaji implementasi metode panel pada airfoil. Dalam hal ini Matlab digunakan sebagai aplikasi dalam memecahkan problem pada aliran potensial multi-elemen berdasarkan metode panel. Perbandingan hasil antara Matlab dan eksperimen, menunjukkan bahwa program aplikasi Matlab menghasilkan kecenderungan yang sama untuk koefisien gaya angkat dan distribusi tekanan. Dengan demikian dapat disimpulkan bahwa metode panel yang diaplikasi pada Matlab dapat digunakan pada beberapa variasi aerodinamis. Hal ini dapat 
digunakan sebagai prosedur optimasi karena perhitungannya dapat mengurangi waktu, dan memungkinkan untuk dijalankannya metode Algoritma Genetika.

Menurut Zhang, dkk (2002) GA efektif dalam memberikan pemecahan masalah yang optimum secara menyeluruh. GA menggunakan teknik pencarian secara acak untuk menemukan pemecahan masalah optimasi dengan menerapkan metode "gen" sebagai model untuk menyelesaikan permasalahan-permasalahan mutasi, seleksi dan pindah silang.

Prosedur algoritma genetika diawali dengan membuat inisial populasi (Purnomo, 2014). Beberapa kromosom membentuk individu, dan beberapa individu yang tergabung membentuk populasi. Individu tersebut dibangkitkan dan kemudian dievaluasi untuk menentukan nilai fitness-nya. Nilai fitness merupakan nilai yang menyatakan kualitas individu, yang diformulasikan dengan fungsi obyektifnya. Setelah evaluasi selanjutya dilakukan seleksi yang berguna untuk menentukan individu yang akan dijadikan induk dalam proses reproduksi. Di dalam proses reproduksi terdapat dua proses yaitu crossover dan mutasi. Anak, hasil reproduksi dari individu, kemudian dievaluasi. Apabila nilai fitness anak lebih baik daripada nilai fitness individu, maka individu tersebut digantikan anak. Hal ini disebut elitsm. Contoh Algoritma Genetika untuk airfoil (Zhang, dkk, 2002).

Misalnya kurva B-spline mewakili geometri airfoil. Nilai $\mathrm{x}$ dan koordinat titik kontrol y digunakan sebagai variabel desain seperti terlihat pada Gambar 1. Ada 8 titik kontrol pada masing-masing sisi tepi bawah dan atas airfoil.

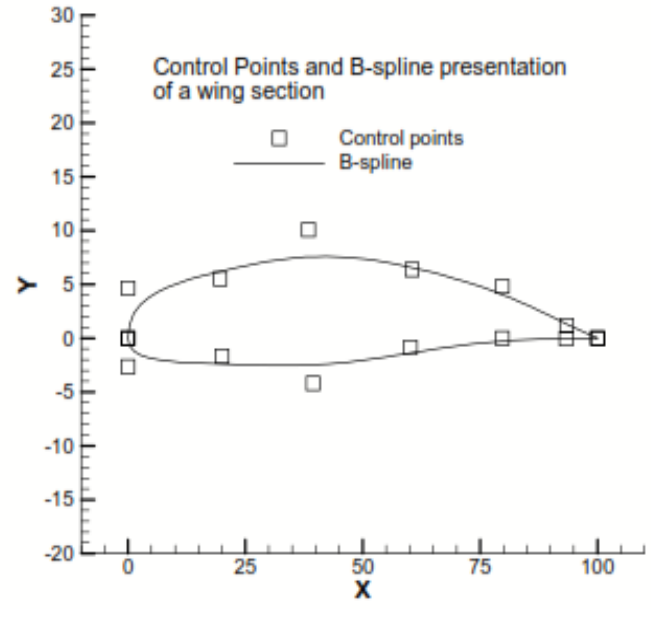

Gambar 1. Kontrol Poin dan Kurva B-spline.

Sejumlah tertentu airfoil terdiri dari populasi. Airfoil adalah kromosom dalam populasi. ukuran populasi kecil dengan menggunakan GA dapat memfasilitasi konvergensi kebugaran. Misal ukuran populasi diatur menjadi 10. Populasi yang dihasilkan dari mutasi oleh airfoil asli itulah yang kemudian dioptimalkan.

Evaluasi fitness merupakan dasar untuk pencarian dan prosedur seleksi GA. GA bertujuan mencari individu (kromosom) dengan nilai kebugaran tinggi dan memilihnya sebagai orang tua untuk mereproduksi keturunan. Tujuan dari optimasi dalam penelitian ini adalah untuk mengurangi drag airfoil dan meningkatkan lift. Oleh karena itu, rasio koefisien lift dan drag digunakan sebagai nilai fitness (fungsi tujuan). Orang tua yang dipilih tersebut didasarkan pada metode roda Roulette dimana kemungkinan orang tua yang dipilih adalah sebanding dengan nilai fitness-nya. Setiap pasang orang tua menghasilkan satu keturunan oleh crossover.

Maka mutasi diterapkan pada keturunan. Setelah populasi baru diproduksi, kebugaran setiap anggota dibandingkan dengan generasi tua dan anggota terbaik (elitisme) ditugaskan untuk menjadi generasi baru. Skema crossover satu titik sederhana adalah diterapkan. Titik crossover dipilih acak. Gambar 2 menunjukkan bagaimana crossover beroperasi. Beberapa variabel desain (titik control) dari anak-airfoil berasal dari ayah-airfoil (kotak) dan beberapa dari ibu-airfoil (silang). Probabilitas crossover 
diatur pada $80 \%$ untuk kinerja Algoritma Genetika.

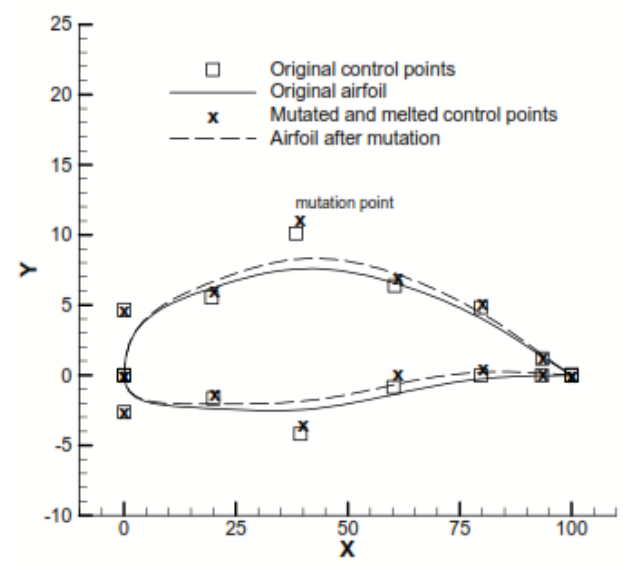

Gambar 2 Crossover

Mutasi dilakukan dengan acak memilih gen (control node) dan mengubah nilainya dengan jumlah dan kisaran yang ditentukan (misal 1\% chord) seperti yang diilustrasikan pada Gambar 3. Karena ini perubahan diterapkan ke node yang dipilih, yang juga disesuaikan pada perubahan kemiringan dan kelengkungan airfoil sehingga profil airfoil tidak akan terlalu miring secara tiba-tiba. Seperti yang dibahas oleh Zhang, dkk (2002) tingkat mutasi yang tinggi untuk kinerja yang lebih baik dan signifikan dipilih pada $80 \%$ jumlah coding GA.

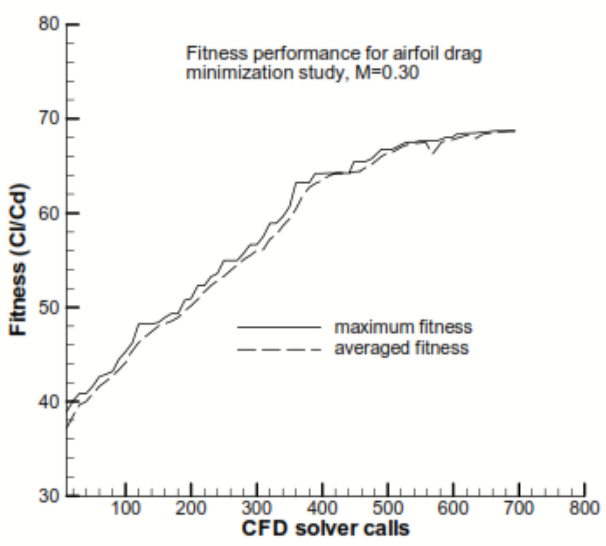

Gambar 3. Fitness Konvergensi

Untuk mendapatkan kendala geometri airfoil yang realistis, seperti minimum yang diijinkan pada ketebalan maksimum (> 8\% chord) dan maksimum yang diizinkan pada sudut trailing edge $\left(5^{\circ}<\alpha<20^{\circ}\right)$. Sehingga hal ini akan dapat mengurangai drag pada jumlah tertentu. Hasil optimasi dapat dilihat pada gambar 4.

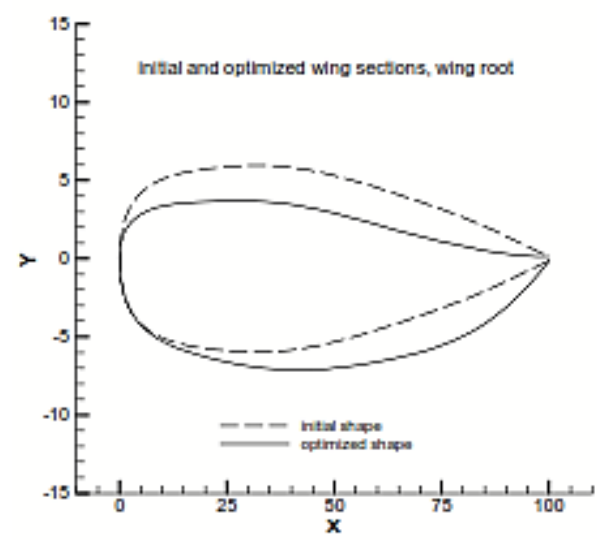

Gambar 4. Airfoil Awal dan Setelah Optimasi

PSO merupakan algoritma berbasis populasi yang mengeksploitasi individu dalam populasi menuju daerah penyelesaian dalam daerah pencarian (Khurana, 2011). Dalam PSO populasi disebut dengan swarm, dan individu disebut dengan particle. Tiap partikel berpindah dengan kecepatan yang diadaptasi dari daerah pencarian dan menyimpannya sebagai posisi terbaik yang pernah dicapai. Prosedur Particle Swarm Optimization dapat dijabarkan dengan langkah-langkah sebagai berikut :

Menurut Khurana (2011), PSO adalah algoritma yang berbasis populasi dimana individu digiring untuk menemukan daerah pencarian pada range daerah penyelesaian. Popula si diistilahkan sebagai swarm, sedangkan individu diistilahkan sebagai particle. Tiap partikel berpindah pada kecepatan yang mengadop daerah pencarian kemudian meny impannya sebagai posisi terbaik yang pemah dicapai.

Prosedur optimasi menggunakan Particle Swarm didiskripsikan dengan yang pertama adalah menentukan ukuran partikel (N) dalam kelompok atau kawanan. Ukuran $\mathrm{N}$ sebaiknya tidak terlalu besar namun juga tidak terlalu kecil,. Idealnya ukuran kelompok adalah 20 sampai dengan 30 partikel. 20 sampai 30 partikel. Selanjutnya menetapkan fungsi tujuan untuk setiap partikel. Hal berikutnya adalah menghitung kecepatan partikel yang bergerak menuju titik optimal. Kecepatan aw al partikel diasumsikan nol. Set iterasi i $=1$. Langkah selanjutnya adalah menentukan 
nilai terbaik dari $P_{\text {best }}$ dan $\mathrm{G}_{\text {best }}$ yang merupakan nilai fungsi tujuan paling minimum diantara semua partikel (kasus minimasi), dan selanjutnya menghitung kecepatan partikel $\mathrm{j}$ pada iterasi ke i. Perhitungan selanjutnya adalah menghitung posisi atau koordinat partikel $\mathrm{j}$ pada iterasi ke-i. kemudian mengevaluasi nilai fungsi tujuan untuk setiap partikel. Langkah berikutnya adalah memeriksa apakah posisi semua partikel menuju ke satu nilai yang sama, (konvergen). Jika belum konvergen maka langkah mengevaluasi nilai diulang dengan memperbarui iterasi $\mathrm{i}=\mathrm{i}+1$. Proses iterasi ini dilanjutkan sampai semua partikel menuju ke satu titik solusi yang sama

\section{METODE PENELITIAN}

Adapun tahapan penelitian dapat dijelaskan sebagai berikut : Pertama penentuan bilangan Reynold yaitu 150,000 serta sudut serang $2^{\circ}, 4^{\circ}$, $6^{\circ}, 8^{\circ}$, dan $10^{\circ}$. Sesuai Williamson, dkk (2012) koordinat foil untuk Joukowsky sudah diketahui. Kemudian, setiap koordinat foil yang diperoleh dianalisis menggunakan JavaFoil (Hepperle, 2011) untuk mendapatkan $C_{L} / C_{D}$ maksimum.

Perhitungan selanjutnya adalah menghitung apakah nilai $C_{L} / C_{D}$ sudah maksimum? Apabila sudah maksimum proses berhenti, artinya didapatkan nilai $C_{L} / C_{D}$ maksimum, namun apabila belum maksimum, geometri foil diupdate dan proses diulang sampai maksimum.

Tahap berikutnya adalah proses optimasi menggunakan GA dan PSO. Pada proses ini sebagai fungsi obyektif adalah $\mathrm{C}_{\mathrm{L}} / \mathrm{C}_{\mathrm{D}}$ maksimum, sedangkan variabel perancangannya adalah koordinat pada foil.

Adapun prosedur yang dilakukan untuk mendapatkan hasil optimasi GA dan PSO dengan pemrograman GNU Octave adalah yang pertama adalah membuka program GNU Octave, kemudian pilih File>New Script. Selanjutnya mengidentifikasikan parameter airfoil yang akan dioptimasi, kemudian parameter-parameter yang diketahui yaitu $\alpha$, dan Reynold number dimasukkan ke dalam file skrip. Selanjutnya menginputkan objective function, variabel desain, serta constraint yang akan digunakan, dan simpan atau run file skrip tersebut. Kemudian menentukan nilai constraint, dan tebakan / perkiraan awal. Selanjutnya masih dalam satu skrip dengan constraint tadi, masukkan nilai tebakan awal agar proses optimisasi dapat dijalankan. Setelah memasukkan constraint, masukkan pula fungsi optimasi (Genetic Algorithm dan Particle Swarm Optimization) yang digunakan untuk meminimasi objective function. Selanjutnya menjalankan proses optimisasi dengan menekan run(nama_file). Setelah hasil optimasi didapat, kemudian dimasukkan pada skrip untuk mendapatkan nilai $C_{L}$ dan $C_{D}$. Selanjutnya $p l o t$ hasil tersebut kedalam sebuah grafik.

\section{HASIL DAN PEMBAHASAN}

Pada riset ini mula-mula menentukan foil Joukowsky dengan menginputkan koordinat foil ke dalam JavaFoil solver (Hepperle, 2011). Gambar 5 berikut menunjukkan profil foil untuk Joukowsky.

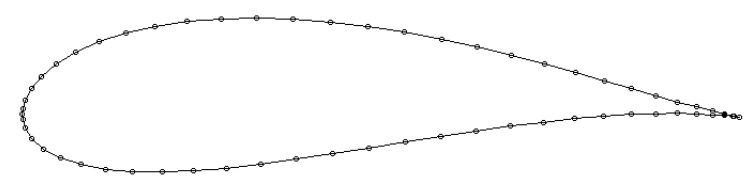

Gambar 5. Profil Joukowsky

Selanjutnya melakukan validasi untuk memastikan bahwa program tersebut bisa digunakan untuk foil apa saja. Dalam hal ini airfoil yang digunkan untuk validasi adalah digunakan adalah airfoil tipe S9000 dan Naca 2415. Simulasi dilakukan dengan mengacu pada hasil eksperimen Williamson, dkk (2012). Gambar 6 dan 7 berikut menunjukkan grafik $C_{L}$ dan $C_{D}$ terhadap sudut serang pada Airfoil S9000 bilangan Reynold 100,144.3.

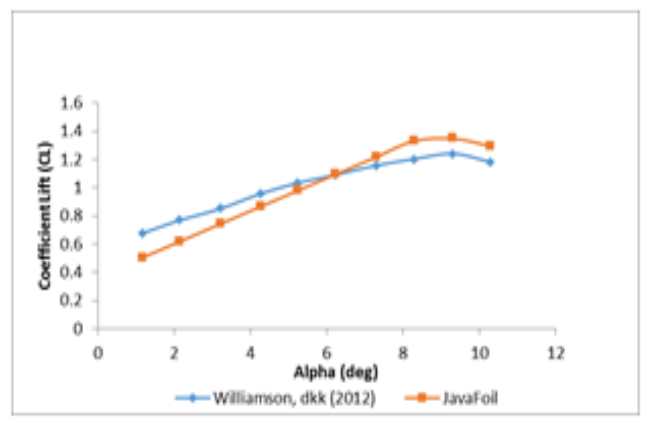

Gambar 6. Validasi $\mathrm{C}_{\mathrm{L}}-\alpha$ Airfoil S9000 
Bilangan Reynold 100,144.3

Pada gambar 6 validasi koefisien lift $\left(C_{L}\right)$ Airfoil S9000 menghasilkan nilai $C_{L}$ hampir sama jika dibandingkan dengan hasil eksperimen Williamson, dkk (2012). Stall terjadi pada sudut serang $9.3^{\circ}$, dengan rata-rata kesalahan sebesar $3.66 \%$. Adapun nilai validasi koefisien $\mathrm{drag}$ $\left(C_{D}\right)$ pada airfoil $\mathrm{S} 9000$ ditunjukkan pada gambar 7 dibawah ini.

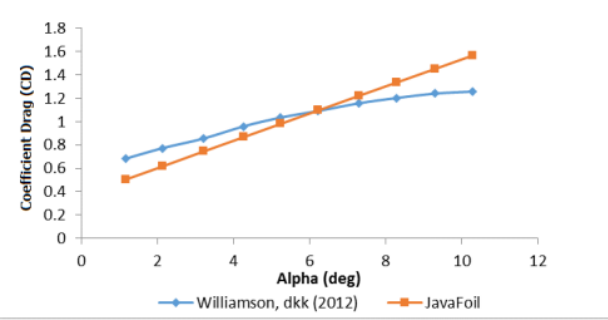

Gambar 7. Validasi $C_{D}-\alpha$ Airfoil S9000 Bilangan Reynold 100,144.3

Pada gambar 7 validasi koefisien $\operatorname{drag}\left(C_{D}\right)$ pada airfoil $\mathrm{S} 9000$ menghasilkan nilai $C_{D}$ hampir sama jika dibandingkan dengan hasil eksperimen Wiliiamson dkk (2012). Rata-rata kesalahan sebesar $6.83 \%$. Kedua hasil validasi tersebut dalam toleransi yang diijinkan sesuai literatur Reid (2002) yaitu dibawah 9.5\%.

Sedangkan validasi koefisien lift $\left(C_{L}\right)$ Airfoil Naca 2415 dengan bilangan Reynold sebesar 101,300 ditunjukkan pada gambar 8 dibawah ini.

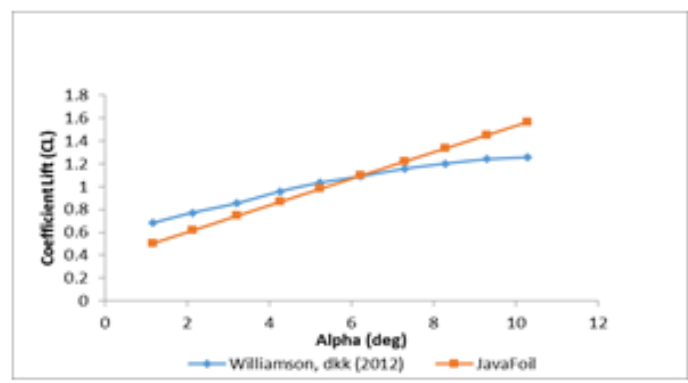

Gambar 8. Validasi $\mathrm{C}_{\mathrm{L}}-\alpha$ Airfoil Naca 2415 Bilangan Reynold 101,300

Pada gambar 8 validasi koefisien lift $\left(C_{L}\right)$ Airfoil Naca 2415 dengan bilangan Reynold sebesar 101,300 menghasilkan nilai $C_{L}$ hampir sama jika dibandingkan dengan hasil eksperimen Wiliiamson dkk (2012). Stall terjadi pada sudut serang $8.92^{\circ}$, dengan rata-rata kesalahan sebesar $1.47 \%$. Sedangkan validasi koefisien $\operatorname{drag}\left(C_{D}\right)$ Airfoil Naca 2415 dengan bilangan Reynold sebesar 101,300 ditunjukkan pada gambar 9 dibawah ini.

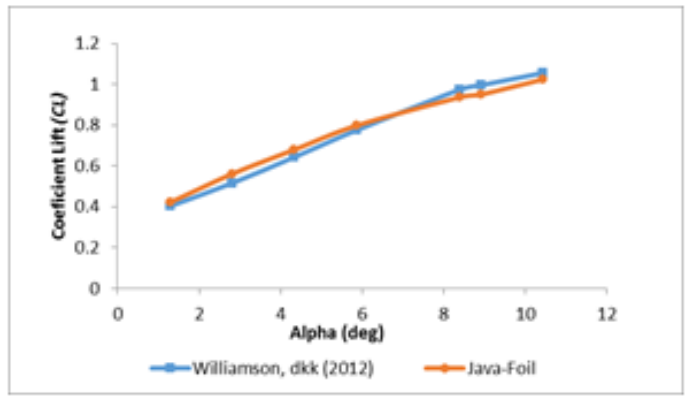

Gambar 9. Validasi $C_{D}-\alpha$ Airfoil Naca 2415 Bilangan Reynold 101,300

Pada gambar 8 Validasi $\mathrm{C}_{\mathrm{D}}-\alpha$ Airfoil Naca 2415 pada Bilangan Reynold 100,144.3 menghasilkan nilai $C_{D}$ hampir sama jika dibandingkan dengan hasil eksperimen Wiliiamson dkk (2012). Rata-rata kesalahan sebesar $8.73 \%$. Kedua hasil validasi ini dalam toleransi yang diijinkan sesuai literatur Reid (2016) yaitu dibawah $9.5 \%$.

\subsection{Optimasi Menggunakan Algoritma Genetika (GA)}

Optimasi dilakukan pada model geometri airfoil Joukowsky dengan menggunakan metode pengoptimasi yaitu Algoritma Genetika (GA) dengan parameter-parameter ditunjukkan pada Tabel 1 berikut :

Tabel 1. Parameter Optimasi Menggunakan Algoritma Genetika (GA)

\begin{tabular}{cc} 
Parameter & Function or Value \\
\hline Population type & Double vector \\
Population size & 20 \\
Generation & 100 \\
Selection & Stochastic uniform \\
Crossover & Scaterred \\
Fitness scaling & Rank \\
\hline
\end{tabular}

Foil tersebut dioptimasi pada bilangan 


\begin{tabular}{lcccccc}
\hline \multirow{2}{*}{ Alpha } & \multicolumn{3}{c}{ Sebelum Optimasi } & \multicolumn{4}{c}{ Optimasi PSO } \\
\cline { 2 - 7 } & $\mathrm{C}_{\mathrm{L}}$ & $\mathrm{C}_{\mathrm{D}}$ & $C_{L} / C_{D}$ & $\mathrm{C}_{\mathrm{L}}$ & $\mathrm{C}_{\mathrm{D}}$ & $C_{L} / C_{D}$ \\
\hline 2 & 0.37 & 0.01 & 32.23 & 0.37 & 0.01 & 33.19 \\
4 & 0.61 & 0.01 & 47.77 & 0.60 & 0.01 & 47.97 \\
6 & 0.83 & 0.02 & 51.14 & 0.81 & 0.02 & 53.21 \\
8 & 0.99 & 0.02 & 48.61 & 0.98 & 0.03 & 33.33 \\
10 & 0.93 & 0.07 & 13.28 & 0.93 & 0.07 & 13.29 \\
\hline Rerat & & & 38.61 & & & 36.20 \\
a & & & & & &
\end{tabular}

Reynold 150,000 sesuai litertur Singh (2014). Masalah optimasi pada penelitian ini diformulasikan sebagai berikut :

$$
\min f(x)=\min \left(-\frac{C_{L}}{C_{D}}\right)_{\max }
$$

Optimasi Algoritma Genetika dapat dilihat pada Tabel 2 dibawah ini.

Tabel 2. Nilai $C_{L} / C_{D}$ Foil Joukowsky Optimasi GA pada Bilangan Reynold 150,000

\begin{tabular}{ccccccc}
\hline \multirow{2}{*}{ Alpha } & \multicolumn{3}{c}{ Sebelum Optimasi } & \multicolumn{3}{c}{ Optimasi GA } \\
\cline { 2 - 7 } & $\mathrm{C}_{\mathrm{L}}$ & $\mathrm{C}_{\mathrm{D}}$ & $C_{L} / C_{D}$ & $\mathrm{C}_{\mathrm{L}}$ & $\mathrm{C}_{\mathrm{D}}$ & $C_{L} / C_{D}$ \\
\hline 2 & 0.37 & 0.01 & 32.23 & 0.35 & 0.01 & 37.41 \\
4 & 0.61 & 0.01 & 47.77 & 0.48 & 0.01 & 51.12 \\
6 & 0.83 & 0.02 & 51.14 & 0.97 & 0.02 & 57.53 \\
8 & 0.99 & 0.02 & 48.61 & 1.15 & 0.02 & 50.42 \\
10 & 0.93 & 0.07 & 13.28 & 0.91 & 0.07 & 12.41 \\
\hline Rerata & & & 38.61 & & & 41.78 \\
\hline
\end{tabular}

Pada tabel 2 terlihat bahwa pada bilangan Reynold yang sama, harga $C_{L}$ semakin besar seiring dengan semakin meningkatnya sudut serang. Seiring dengan kenaikan sudut serang, aliran udara cenderung mengalami separasi (pemisahan) pada permukaan foil, sehingga terbentuk wake (ulakan) di belakang foil. Terjadinya separasi aliran ini menyebabkan berkurangnya lift dan meningkatnya drag.

\subsection{Optimasi Menggunakan Particle Swarm Optimization (PSO)}

Fungsi PSO dalam penelitian ini terdiri dari 4 bagian yaitu inisialisasi parameter permasalahan, inisialisasi solusi, manipulasi solusi dan menampilkan output. Adapun nilai
$C_{L} / C_{D}$ foil Joukowsky optimasi Particle Swarm ditunjukkan dalam Tabel 3

Tabel 3. Nilai $C_{L} / C_{D}$ Foil Joukowsky Optimasi Particle Swarm pada Bilangan Reynold 150,000

Pada tabel 3 terlihat bahwa pada bilangan Reynold yang sama, harga $C_{L}$ semakin besar seiring dengan semakin meningkatnya sudut serang. Seiring dengan kenaikan sudut serang, aliran udara cenderung mengalami separasi (pemisahan) pada permukaan foil, sehingga terbentuk wake (ulakan) di belakang foil. Terjadinya separasi aliran ini menyebabkan berkurangnya lift dan meningkatnya drag.

\subsection{Perbandingan Optimasi Menggunakan Algoritma Genetika dan Particle Swarm (PSO)}

Berikut tabel rekapitulasi perbandingan optimasi menggunakan Algoritma Genetika (GA) dan Patricle Swarm (PSO) airfoil Joukowski.

Tabel 4. Rekapitulasi Perbandingan $C_{L} / C_{D}$ Maksimum

\begin{tabular}{ccc}
\multirow{2}{*}{ Alpha } & \multicolumn{2}{c}{ Peningkatan dibanding sebelumnya (\%) } \\
\cline { 2 - 3 } & GA & PSO \\
\hline 2 & 16.07 & 2.97 \\
4 & 7.01 & 0.43 \\
6 & 12.51 & 4.06 \\
8 & 3.72 & 31.43 \\
10 & 6.59 & 0.01 \\
\hline Rerata & 6.54 & 4.79 \\
\hline
\end{tabular}

Optimasi dengan GA menghasilkan ratarata nilai $C_{L} / C_{D}$ sebesar 41.777 , sehingga peningkatan $6.54 \%$ dari sebelum dioptimasi., sedangkan dengan PSO menghasilkan rata-rata nilai $C_{L} / C_{D}$ sebesar 36.20 , sehingga peningkatan $4.79 \%$ dari sebelum dioptimasi.

Dengan melihat tabel 4 dapat diamati bahwa airfoil yang dioptimasi dengan Algoritma Genetika memiliki karakteristik aerodinamik 
yang lebih baik dibandingkan dengan airfoil awal. Peningkatan $C_{L} / C_{D}$ tersebut signifikan sampai $6.54 \%$ pada airfoil Joukowski sehingga dapat dikatakan bahwa metode Algoritma Genetika (GA) ini bisa menjadi salah satu alternatif optimization tool yang digunakan dalam masalah optimasi airfoil pada bilangan Reynold rendah.

Selanjutnya geometri foil Joukowsky awal, optimasi GA dan PSO pada dan Bilangan Reynold 150,000 ditampilkan dalam gambar 10 sampai dengan 14 berikut :

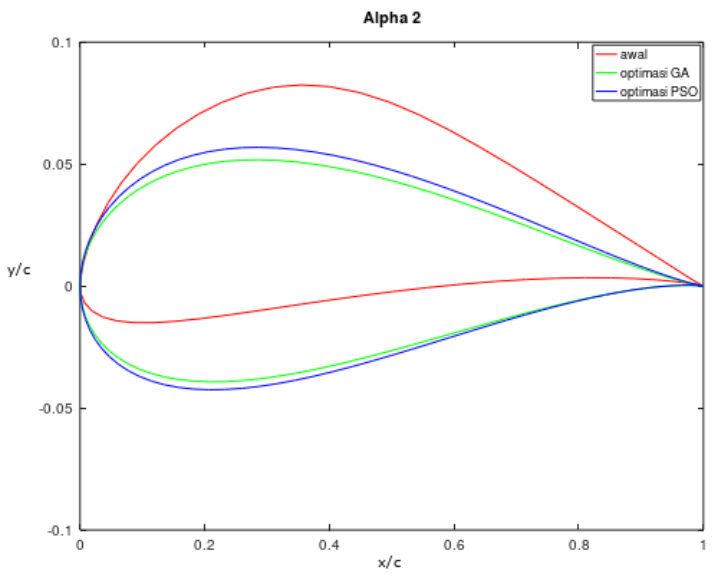

Gambar 10. Foil Joukowsky Awal, Optimasi GA dan PSO Bilangan Reynold 150,000 Alpha $2^{\circ}$

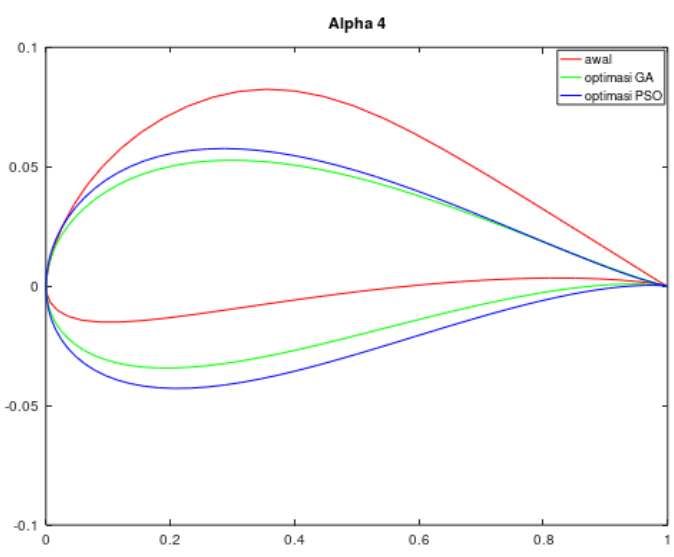

Gambar 11. Foil Joukowsky Awal, Optimasi GA dan PSO Bilangan Reynold 150,000 Alpha $4^{\circ}$

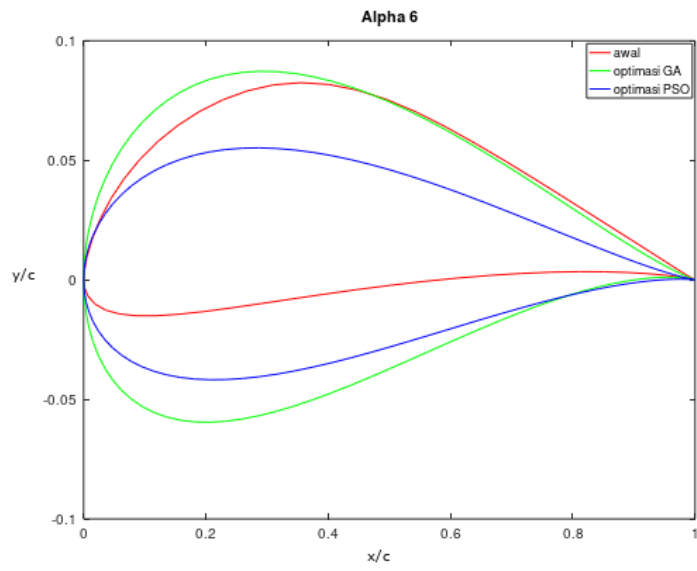

Gambar 12. Foil Joukowsky Awal, Optimasi GA dan PSO Bilangan Reynold 150,000 Alpha $6^{\circ}$

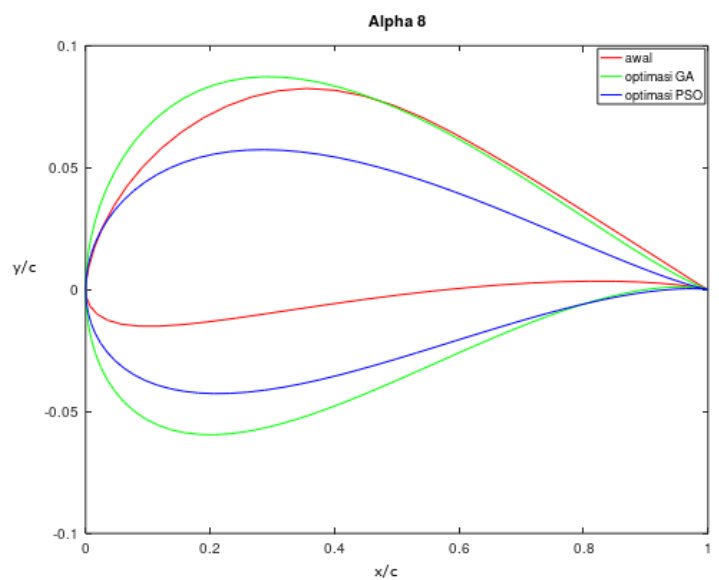

Gambar 13. Foil Joukowsky Awal, Optimasi GA dan PSO Bilangan Reynold 150,000 Alpha $8^{\circ}$

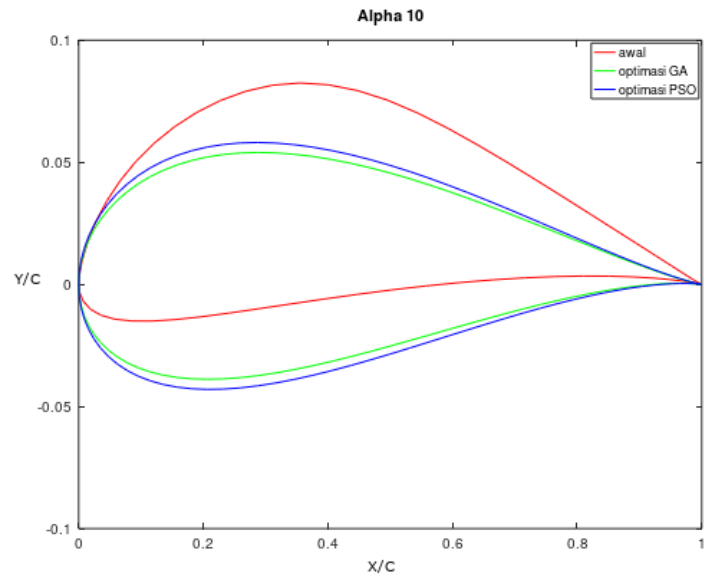

Gambar 14. Foil Joukowsky Awal, Optimasi GA dan PSO Bilangan Reynold 150,000 Alpha 10 
Optimasi dengan GA memiliki kecepatan konvergensi yang cukup tinggi di awal pemcarian, kemudian diikuti proses stagnasi, dimana solusi yang dihasilkan membaik secara signifikan. Sedangkan PSO pencarian solusi terbaik difokuskan pada pencarian local sehingga ada kalanya keluar dari daerah pencarian yang mengakibatkan konvergensi sulit dicapai atau lambat. Pada kasus ini optimasi airfoil yang disarankan adalah menggunakan Algoritma Genetika.

\section{KESIMPULAN}

Solver JavaFoil yang digunakan dalam proses validasi pada penelitian ini, memberikan hasil akurat, dengan error sebesar $4.15 \%$. Optimasi dengan GA menghasilkan rata-rata nilai $C_{L} / C_{D}$ sebesar 41.777 , sehingga peningkatan $6.544 \%$ dari sebelum dioptimasi. Sedangkan dengan PSO rata-rata nilai $C_{L} / C_{D}$ sebesar 36.197, sehingga peningkatan $4.793 \%$ dari sebelum dioptimasi. Hal ini dikarenakan Algoritma Genetika dikarenakan GA mampu mencari solusi global atau yang mendekati solusi global optimum.

\section{REFERENSI}

Ashraf, M. A., dkk. 2011. Reynolds Number, Thickness and Camber Effects on Flapping Airfoil Propulsion. Journal of Fluids and structures. 27(2) 145-160.

Hepperle, Martin. 2011. Javafoil User's Guide.

Herraprastanti, E.H. 2018. Buku Ajar Metode Numerik Aplikasi dan Optimasi dengan GNU Octave. JDS, Surabaya. 59-81.

Khurana, M., Winarto, H. and Sinha, A. 2015. Swarm Algoritma with Adaptive Mutation for Airfoil Aerodynamics Design. Oxford : ELSEVIER.

Mukesh, R., et al. 2012. Influence of Search Algoritmas on Aerodynamic Design Optimisation of Aircraft Wings. Procedia engineering. 38: 2155-2163.

Purnomo, H.D. 2014. Cara Mudah Belajar Metode Optimisasi Metaheuristik Menggunakan Matlab. Gava Media (1), Yogyakarta.

Reid, Michael. 2006. Thin/Cambered/Reflexed Airfoil Development for Micro-Air Vehicles at Reynolds Numbers of 60,000 to 150,000 .

Suryadi, Aji; dkk. 2017. Analisa Pengaruh Sudut Serang Foil Terhadap Gaya Angkat Kapal Trimaran Foil. Jurnal Teknik ITS, 5.(2).

Williamson, G.A., dkk. 2012. Summary of Low Speed Airfoil Data. Departemen of Aerospace Engineering University of Illinois Urbana-Champaign.

Zhang, F., Chen, S., \& Khalid, M. 2002. Optimizations of Airfoil and Wing Using Genetika Algoritma. ICAS. 